\begin{tabular}{|c|c|c|c|}
\hline $\begin{array}{l}\text { 4. Relat } \\
\text { NA }\end{array}$ & ed EDT N & & \\
\hline $\begin{array}{l}\text { 7. Purch } \\
\text { NA }\end{array}$ & lase Order & No.: & \\
\hline $\begin{array}{l}\text { 9. Equip } \\
\text { NA }\end{array}$ & /Compon & nt No: & \\
\hline $\begin{array}{l}\text { 10. Syst } \\
\text { CVDF/ }\end{array}$ & $\begin{array}{l}\text { em/Bldg. } / \mathrm{f} \\
142 \mathrm{~K}\end{array}$ & acility: & \\
\hline $\begin{array}{l}\text { 12. Majo } \\
\text { NA }\end{array}$ & Assm. D & Ng. No.: & \\
\hline $\begin{array}{l}\text { 13. Perm } \\
\text { NA }\end{array}$ & nit/Permit & pplicatio & No.: \\
\hline 14. Requ & dired Resp & onse Dat & \\
\hline$(F)$ & (G) & $(H)$ & (I) \\
\hline $\begin{array}{l}\text { Approval } \\
\text { Desig- } \\
\text { nator }\end{array}$ & $\begin{array}{l}\text { Reason } \\
\text { for Trans- } \\
\text { mittal }\end{array}$ & $\begin{array}{l}\text { Origi- } \\
\text { nator } \\
\text { Dispo- } \\
\text { stion }\end{array}$ & $\begin{array}{c}\text { Receiv- } \\
\text { er } \\
\text { Dispo- } \\
\text { sition }\end{array}$ \\
\hline NA & 2 & 1 & \\
\hline $\mathrm{NA}$ & 2 & 1 & \\
\hline NA & 2 & 1 & \\
\hline NA & 2 & 1 & \\
\hline & & & \\
\hline & & & \\
\hline & & & \\
\hline
\end{tabular}

KEY
No

2

\begin{tabular}{|l|}
\hline $\begin{array}{l}\text { 2. To: (Receiving Organization) } \\
\text { Distribution }\end{array}$ \\
\hline $\begin{array}{l}\text { 5. Proj./Prog./Dept./Div.: } \\
\text { SNF Project/W- } 441\end{array}$ \\
\hline 8. Originator Remarks:
\end{tabular}

3. From: (Originating Organization)
Technical Integration
$\begin{aligned} & \text { 6. Design Authority/Design Agent/Cog. Engr.: } \\ & \text { C. C. Pitkoff }\end{aligned}$

8. Originator Remarks

For approval and release.

11. Receiver Remarks:

\begin{tabular}{|l|l|}
\hline 16. \\
\hline Approval Designator (F) & \\
\hline $\begin{array}{c}\text { E, S, Q, D OR N/A } \\
(\text { See WHC-CM-3-5, } \\
\text { Sec. 12.7) }\end{array}$ & $\begin{array}{l}\text { 1. Approval } \\
\text { 2. Release } \\
\text { 3nformation }\end{array}$ \\
\hline
\end{tabular}

17.
SIGNATURE/DISTRIBUTION

Reason for Transmittal (G)

4. Review

5. Post-Review

6. Dist. (Receipt Acknow. Required)
15 (See Approval Designator for required signatures)

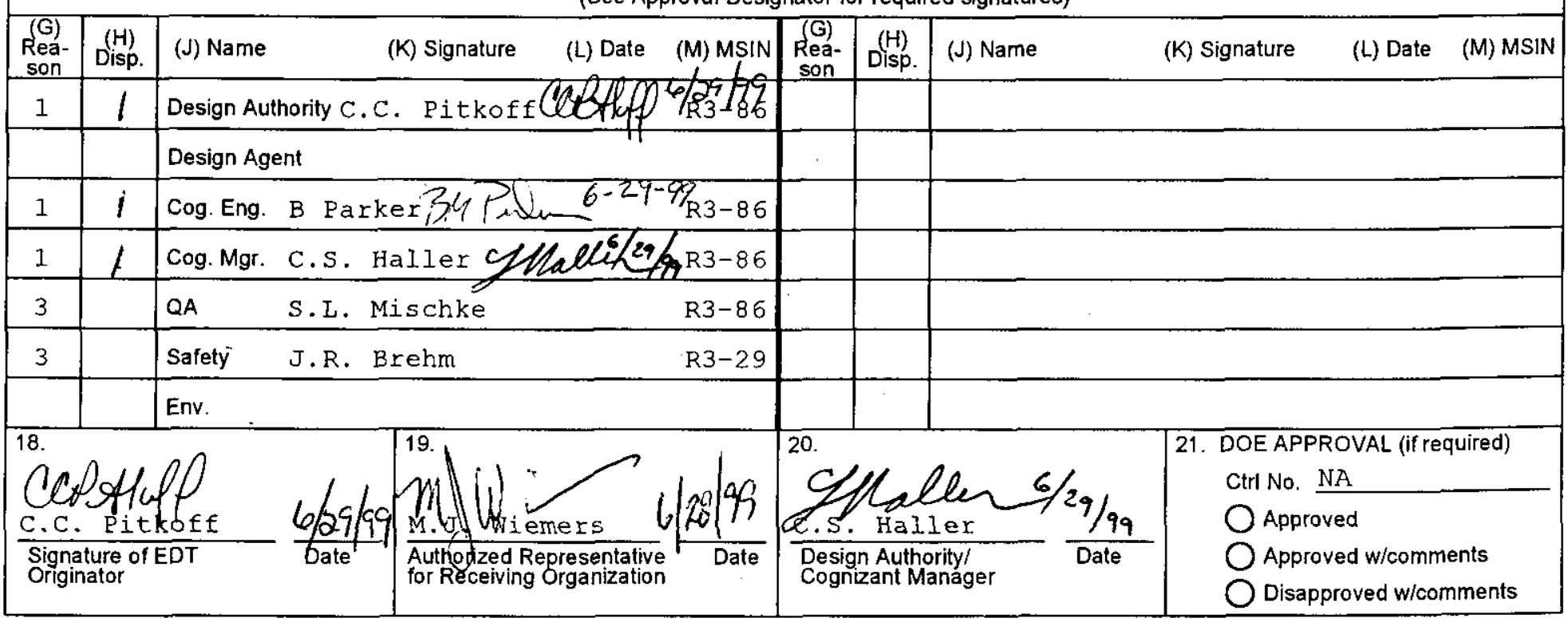




\title{
Cold Vacuum Drying Facility Sanitary Sewage Collection System Design Description
}

\author{
C. C. Pitkoff \\ DE\&S Hanford, \\ Richland, WA 99352 \\ U.S. Department of Energy Contract DE-AC06-96RL13200 \\ EDT/ECN: 626308 (JLB $6 / 30199)$ UC: 510 \\ Org Code: $2 \mathrm{~F} 800$ \\ CACN: 105568 \\ COA: $A 000$ \\ B\&R Code: 39EW70400 Total Pages: 24 (JKB $6 / 30 / 99$ )
}

Key Words: SNF, CVD, W-441, design description, SANS, sanitary sewer, collection, sanitary sewage collection system

Abstract: This document describes the Cold Vacuum Drying Facility (CVDF) sanitary sewage collection system. The sanitary sewage collection system provides collection and storage of effluents and raw sewage from the CVDF to support the cold vacuum drying process. This system is comprised of a sanitary sewage holding tank and pipes for collection and transport of effluents to the sanitary sewage holding tank.

TRADEMARK DISCLAIMER, Reference herein to any specific commercial product, process, or service by trade name, trademark. manufacturer. or otherwise, does not necessarily constitute or imply its endorsement, recommendation, or favoring by the United States Government or any agency thereof or its contractors or subcontractors.

Printed in the United States of America. To obtain copies of this document, contact: Document Control Services, P. O. Box 950, Mailstop H6-08, Richland WA 99352. Phone (509) 372-2420: Fax (509) 376-4989.
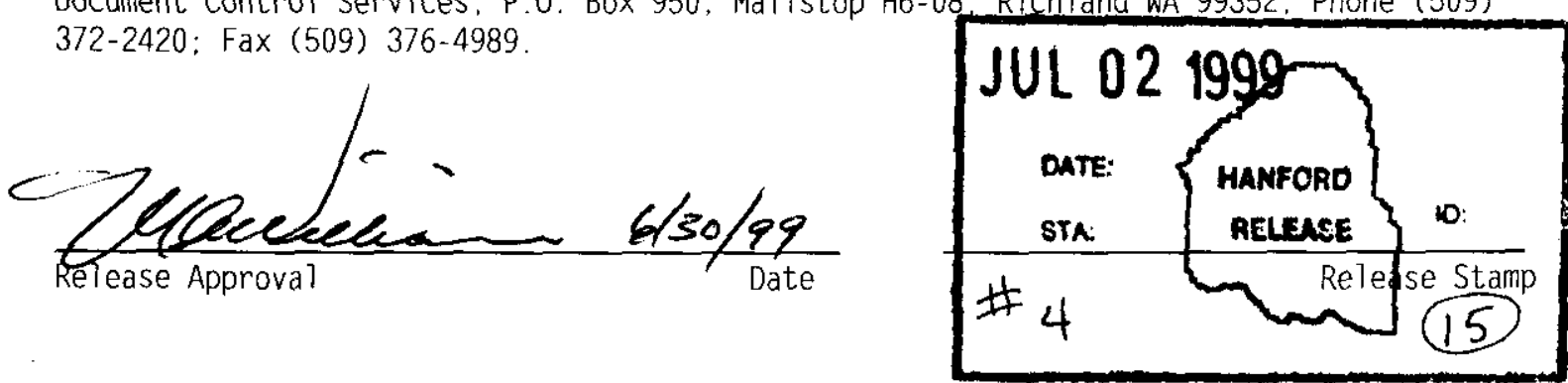

\section{Approved for Public Release}


SNF-3080 Rev 0

COLD VACUUM DRYING FACILITY

SANITARY SEWAGE COLLECTION SYSTEM

DESIGN DESCRIPTION

SYSTEM 27 


\section{TABLE OF CONTENTS}

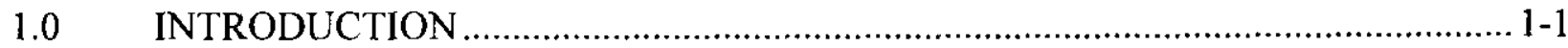

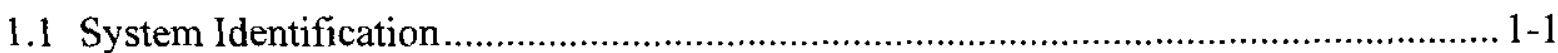

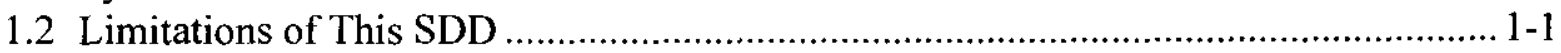

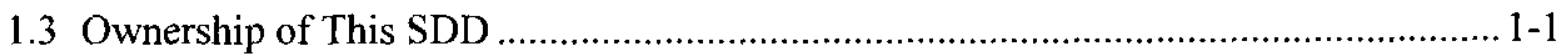

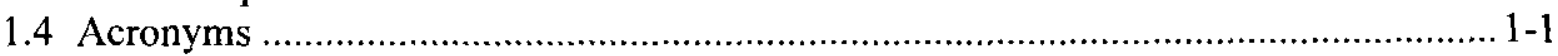

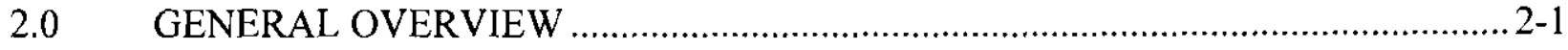

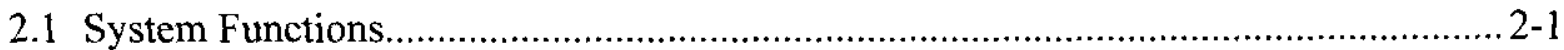

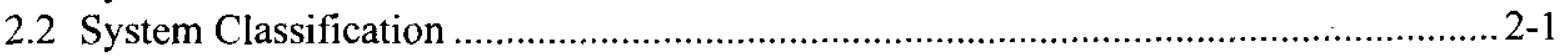

2.3 Basic Operational Overview........................................................................... 2-1

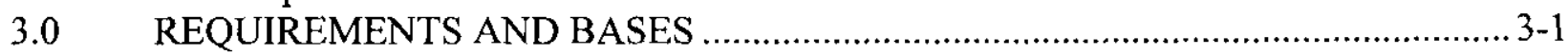

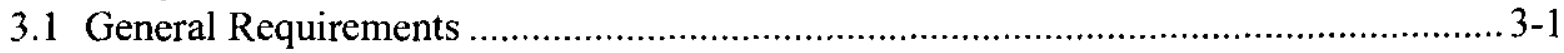

3.1.1 System Functional Requirements ..................................................... 3-1

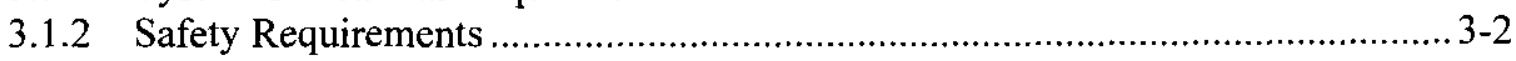

3.1.3 Mission Critical Requirements ........................................................ 3-2

3.1.4 General Requirements...................................................................... $3-3$

3.1.5 Subsystem and Major Components ......................................................... 3-3

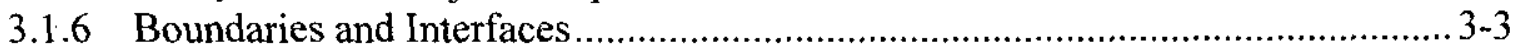

3.1.7 Codes, Standards, and Regulations ....................................................... 3-3

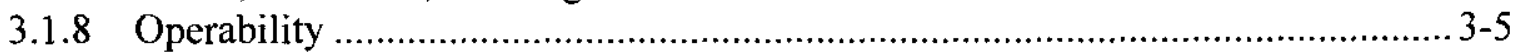

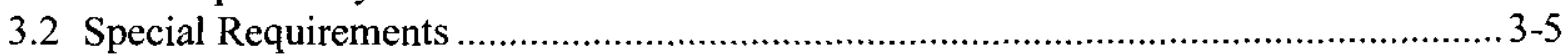

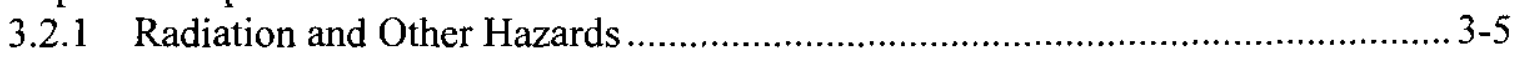

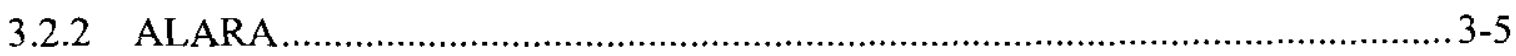

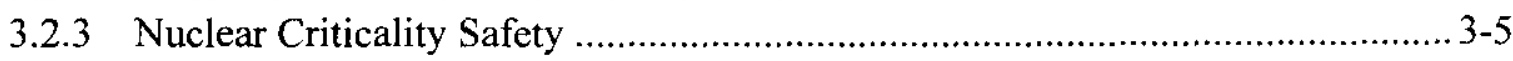

3.2.4 Industrial Hazards ................................................................................... $3-5$

3.2.5 Operating Environment and Natural Phenomena ......................................... 3-5

3.2.6 Human Interface Requirements .......................................................... 3-5

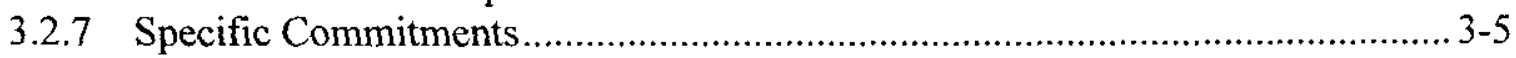

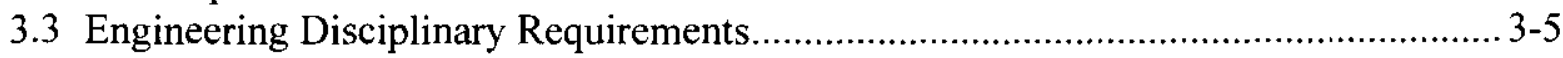

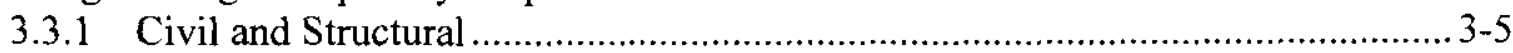

3.3.2 Mechanical and Materials .................................................................. 3-6

3.3.3 Chemical and Process ....................................................................................... 3-6

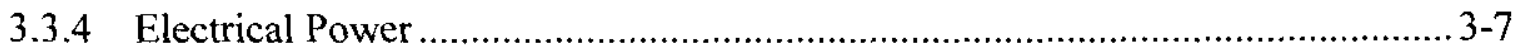

3.3.5 Instrumentation and Control .................................................................... 3-7

3.3.6 Computer Hardware and Software ............................................................ $3-7$

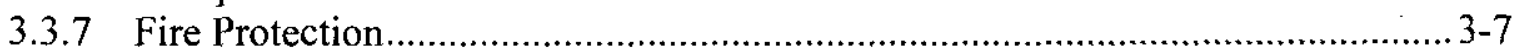

3.4 Testing And Maintenance Requirements ........................................................ 3-7

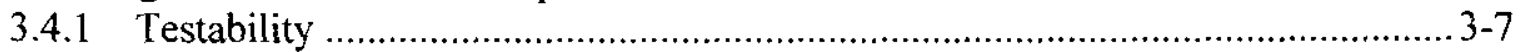

3.4.2 Technical Safety Requirements (TSR) Required Surveillances ....................... 3-7

3.4.3 Non-TSR Inspections and Testing ............................................................. 3-7

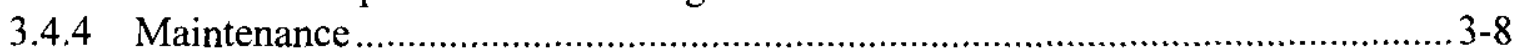

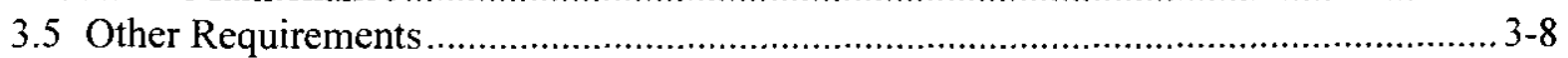

3.5.1 Security and SNM Protection ................................................................... 3-8

3.5.2 Special Installation Requirements......................................................... 3-8

3.5.3 Reliability, Availability, and Preferred Failure Modes.................................... 3-8 
3.5.4 Quality Assurance .................................................................................... 3-8

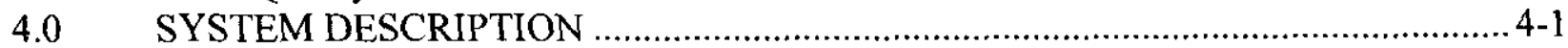

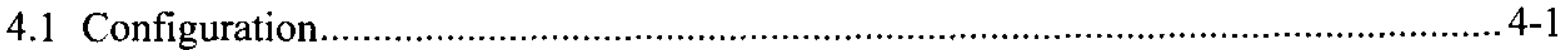

4.1.1 Description of System, Subsystems, and Major Components ............................. 4-1

4.1.2 Boundaries and Interfaces........................................................................ 4-2

4.1.3 Physical Location and Layout......................................................................... 4-2

4.1.4 Principles of Operation .......................................................................... 4-2

4.1.5 System Reliability ................................................................................... 4-2

4.1.6 System Control Features ................................................................................. 4-2

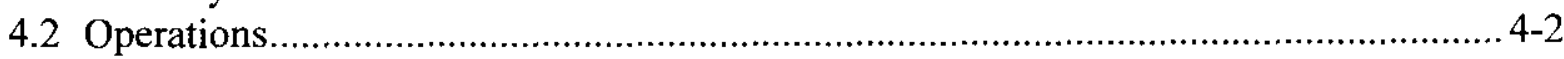

4.2.1 Initial Configurations (Pre-startup) ................................................................ 4-2

4.2.2 System Startup .................................................................................... 4-2

4.2.3 Normal Operations .................................................................................... 4-3

4.2.4 Off-Normal Operations ............................................................................ 4-3

4.2.5 System Shutdown .................................................................................... 4-3

4.2.6 Safety Management Programs and Administrative Controls.............................. 4-3

4.3 Testing And Maintenance........................................................................................ 4-3

4.3.1 Temporary Configurations ……………......................................................... 4-3

4.3.2 TSR-Required Surveillances....................................................................... 4-3

4.3.3 Non-TSR Inspections, and Testing ............................................................. 4-3

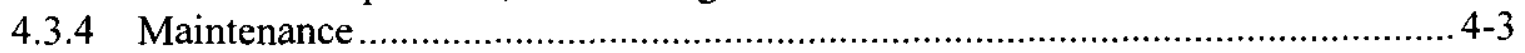

APPENDIX A. Source Documents............................................................................... A-1

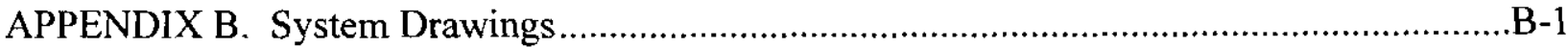

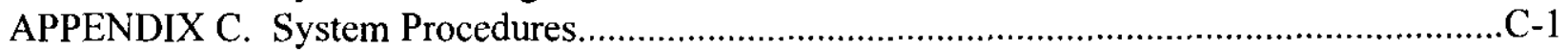


SNF-3080 Rev 0

\section{LIST OF FIGURES}

Figure 3-1. Sanitary Sewage Collection System Layout .......................................................... 3-4 


\subsection{INTRODUCTION}

\subsection{System Identification}

The scope of this System Design Description (SDD) is the Sanitary Sewage Collection System (SANS), which provides collection and storage of effluents and raw sewage from the Cold Vacuum Drying (CVD) Facility to support the cold vacuum drying process. This system is comprised of a sanitary sewage holding tank and pipes for collection and transport of effluents to the sanitary sewage holding tank. Figure 3-1 shows the configuration of this system.

\subsection{Limitations of This SDD}

This SDD has been prepared with best available information taken from reviewed and approved design documents and drawings.

This SDD, when used in conjunction with the other elements of the definitive design package, provides a complete picture of the SANS. Elements of SDD include functions, requirements, and descriptions. Other documents comprising the definitive design of the system include:

- $\quad$ Project design requirements (HNF-SD-SNF-DRD-002)

- $\quad$ Master equipment list (SNF-4148)

- Data and calculation matrix tracking list (SNF-3001)

- $\quad$ Sequence of operations (see HNF-2356)

\subsection{Ownership of This SDD}

The CVD Facility Design Authority assigned to this system is responsible for the accuracy and technical content of this SDD. Any questions on the system or content of this document shall be resolved through the design authority.

\subsection{Acronyms}

$\begin{array}{ll}\text { ABS } & \text { Acrylonitrile-Butadiene-Styrene } \\ \text { CVD } & \text { Cold Vacuum Drying } \\ \text { MCS } & \text { Monitoring and Control System } \\ \text { SANS } & \text { Sanitary Sewage Collection System } \\ \text { SDD } & \text { System Design Description } \\ \text { TSR } & \text { Technical Safety Requirements } \\ \text { UPC } & \text { Uniform Plumbing Code } \\ \text { VTR } & \text { Vent Through the Roof } \\ \text { WAC } & \text { Washington Administrative Code }\end{array}$


SNF-3080 Rev 0

\subsection{GENERAL OVERVIEW}

\subsection{System Functions}

The sanitary sewage collection system provides sanitary waste collection from the lavatory sinks, water closets, urinals, showers, custodial service sinks, drinking fountains and floor drains. It provides temporary storage for the sanitary waste in a holding tank on the west side of the CVD Facility.

\subsection{System Classification}

The system is classified as general service and Performance Category 1 .

\subsection{Basic Operational Overview}

The CVD Facility is not served by the site-wide sanitary sewer system. Sanitary sewage generated in the CVD Facility is collected in a piping system within the facility and transported via gravity flow to a holding tank sited near the CVD Facility. The tank will be pumped periodically by a truck designed for such purposes. 


\subsection{REQUIREMENTS AND BASES}

\subsection{General Requirements}

\subsubsection{System Functional Requirements}

Functional requirements of the sanitary collection system include design requirements, environmental requirements, and general requirements.

\subsubsection{Design Requirements}

1. Requirement: The CVD Facility shall not be served by a site wide sanitary sewage system. Sanitary sewage generated in the CVD Facility shall be collected in a holding tank sited near the CVD Facility.

Basis: HNF-SD-SNF-DRD-002, Rev. 4, Section 6.6.4.5.a. Since the CVD Facility is a temporary facility, with a design life of only 5 years, and the $100 \mathrm{~K}$ Area does not have a site wide sanitary sewage system, it would be cost prohibitive to install anything beyond a holding tank type system for sanitary sewage collection.

How the system meets the requirement: Sanitary sewage generated in the CVD Facility is collected in a holding tank sited near the CVD Facility.

2. Requirement: The tank shall be sized to retain sewage generated by 45 persons per day. Fourteen persons will shower each day. The regular pumping schedule shall be a maximum of twice per week. The tank shall be buried no deeper than required to provide gravity drain from the facility and to meet structural requirements.

Basis: HNF-SD-SNF-DRD-002, Rev. 4, Section 6.6.4.5.b. The CVD Facility is anticipated to have a staff of approximately 45 personnel, with the operations personnel utilizing the showers. The typical pumping schedule for other sanitary sewage tanks at Hanford is twice per week.

How the system meets the requirement: Sanitary sewage generated in the CVD Facility is collected in a holding tank sited near the CVD Facility. The tank is sized to retain sewage generated by 45 persons per day, including fourteen persons showering each day. The regular pumping schedule is twice per week. The tank is buried no deeper than required to provide gravity drain from the facility and to meet structural requirements.

3. Requirement: There shall be no hard connections to the sanitary sewage system in the process areas of the CVD Facility. 
Basis: HNF-SD-SNF-DRD-002, Rev. 4, Section 6.6.4.5.c. No hard connections should be made to the sanitary sewage collection system in the process areas of the CVD Facility to avoid any process wastes from contaminating the sanitary sewage collection system.

How the system meets the requirement: Sanitary sewage generated in the CVD Facility is collected in a holding tank sited near the CVD Facility. There are no hard connections to the sanitary sewage system in the process areas of the CVD Facility.

4. Requirement: The sanitary sewer plumbing shall be designed and constructed in accordance with the Uniform Plumbing Code (UPC).

Basis: HNF-SD-SNF-DRD-002, Rev. 4, Section 6.6.4.5.d. The UPC is the standard code used for sanitary sewer plumbing.

How the system meets the requirement: Sanitary sewage generated in the CVD Facility is collected in a holding tank sited near the CVD Facility. The sanitary sewer plumbing is designed and constructed in accordance with the UPC.

\subsubsection{Safety Requirements}

3.1.1.2.1 Safety Class Requirements. There are no safety class requirements for the sewage collection system.

3.1.1.2.2 Safety Significant Requirements. There are no safety significant requirements for the sewage collection system.

3.1.1.2.3 Other Safety Requirements. There are no other safety requirements for the sewage collection system.

\subsubsection{Environmental Requirements}

1. Requirement: The sanitary sewage holding tank shall be designed and installed in accordance with Washington Administrative Code (WAC) 246-272-12501, "Holding Tank Sewage Systems".

Basis: HNF-SD-SNF-DRD-002, Rev. 4, Section 6.6.4.5.e. WAC-246-272-12501 is required by the State of Washington.

How the system meets the requirement: The sanitary sewage holding tank is designed and installed in accordance with WAC 246-272-12501, "Holding Tank Sewage Systems".

\subsubsection{Mission Critical Requirements}

There are no mission critical requirements for the sewage collection system. 


\subsubsection{General Requirements}

There are no general requirements for the sanitary sewage collection system.

\subsubsection{Subsystem and Major Components}

The system consists of Acrylontrile-Butadiene-Styrene and Polyvinyl Chloride piping to collect and transport sanitary wastes and liquid effluent from plumbing fixtures and floor drains in the administration area and the process support area to an underground fiberglass holding tank located on the west side of the administration building. The tank is equipped with a vent to atmosphere, a pump out connection, a manway (normally sealed), and two level indicators/alarms. The tank is partially overlain with a concrete pad to control runoff. See Figure 3-1 for details.

\subsubsection{Boundaries and Interfaces}

The boundaries and interfaces of the system are the plumbing fixtures and the floor drains in the administration area; the process support area; and the holding tank. The holding tank interfaces with the atmosphere through a vent pipe, the monitoring and control system (MCS) through level indicators/alarms, and the site sanitary waste collection truck.

\subsubsection{Codes, Standards, and Regulations}

ASTM A53-95A, Pipe, Steel, Black And Hot-Dipped, Zinc Coated Welded And Seamless, American Society For Testing And Materials, West Conshohocken, Pennsylvania.

ASTM D 4021-86, Glass Fiber Reinforced Polyester Underground Petroleum Storage Tanks, American Society For Testing And Materials, West Conshohocken, Pennsylvania.

ASTM D 2661-95, Acrylonitrile-Butadiene-Styrene (ABS), Schedule 40 Drain, Waste and Vent Pipe and Fittings, American Society For Testing And Materials, West Conshohocken, Pennsylvania.

ASTM D 3034-95, Type PSM Poly Vinyl Chloride Sewer Pipe and Fittings, American Society for Testing and materials, West Conshohocken, Pennsylvania

UL-1316, Glass Fiber Reinforced Plastic Underground Storage Tanks for Petroleum Products, Underwriters Laboratory, Northbrook, Illinios.

UPC, 1994, Uniform Plumbing Code, International Association of Plumbing and Mechanical Officials, Walnut Creek, California.

WAC 246-272, "On-site Sewage Systems" 
Figure 3-1. Sanitary Sewage Collection System Layout

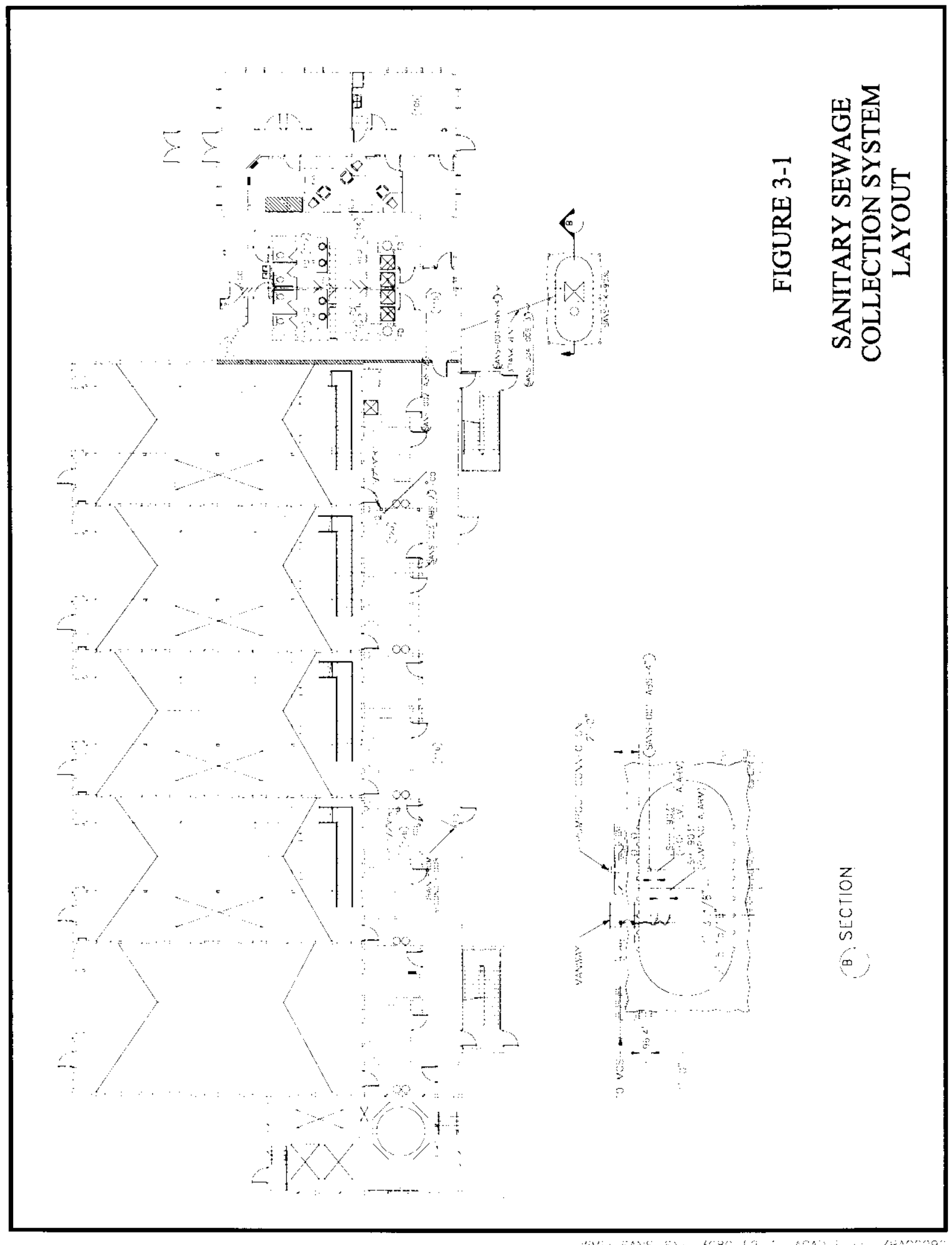




\subsubsection{Operability}

There are no unique operability requirements for this system.

\subsection{Special Requirements}

\subsubsection{Radiation and Other Hazards}

This section does not apply to this SDD.

\subsubsection{ALARA}

This section does not apply to this SDD.

\subsubsection{Nuclear Criticality Safety}

This section does not apply to this SDD.

\subsubsection{Industrial Hazards}

This section does not apply to this SDD.

\subsubsection{Operating Environment and Natural Phenomena}

This section does not apply to this SDD.

\subsubsection{Human Interface Requirements}

The holding tank is accessed through a normally sealed pipe inlet on the top of the tank for the purpose of pumping the residual liquid wastes from the tank. There is a normally sealed manway through the top of the tank for entry if required.

\subsubsection{Specific Commitments}

This section does not apply to this SDD.

\subsection{Engineering Disciplinary Requirements}

\subsubsection{Civil and Structural}

1. Requirement: The holding tank shall withstand external hydrostatic pressure equivalent to being buried in the ground with 7 feet of overburden over the top of the tank and with the hole fully flooded, with safety factor of 5:1 against general buckling.

- $\quad$ Surface loads: Must be able to withstand H-20 axle loads (32,000 lbs/axle). 
- Internal loads: Tank must withstand pressure test of 5 psi if 4-foot through 10foot in diameter, $3 \mathrm{psi}$ if 12-foot in diameter, with 5:1 safety factor.

- Tank must be designed to support accessory equipment such as ladders, piping, etc., when installed according to manufacturer's recommendations and limitations.

- $\quad$ Tank must be vented.

Basis: WAC 246-272-12501, "Holding Tank Sewage Systems" and standard engineering design practices for sanitary sewage collection systems.

How the system meets the requirements: The tank is designed to meet these requirements as detailed in the Construction Specification for the Cold Vacuum Drying Facility, W-441-C1, and on drawings H-1-82124, Sheet 2 of 2, and H-1-82229 Sheet 1 of 2. A 4-in. by 4-in. concrete slab, 4 -in. thick with \#4 rebar (15-in. centers, each way) over 4-in. of 5/8-in. crushed rock, is placed around the pump out connection to the tank.

\subsubsection{Mechanical and Materials}

1. Requirement: The interior sanitary sewer piping is to be ASTM D-2661 ABS. The exterior buried pipe is to be cast iron no-hub under the building and ASTM D-3034 PVC outside of the building. The holding tank vent pipe is to be ASTM A-53 galvanized carbon steel, routed to the west wall of the administration building and vertically up the wall to a point above the roof of the administration building. The tank is to be constructed of ASTM D-2021 glass fiber reinforced polyester.

Basis: WAC 246-272-12501, "Holding Tank Sewage Systems" and standard engineering design practices for sanitary sewage collection systems.

How the system meets the requirements: The piping and tank are designed to meet these requirements as detailed in the Construction Specification for the Cold Vacuum Drying Facility, W-441-C1, and on drawings H-1-82225, sheet 1 of 1, and H-1-82229, sheet 1 of 2 .

\subsubsection{Chemical and Process}

1. Requirement: Tank capacity shall be 5000 gallons

Basis: WAC 246-272-12501, "Holding Tank Sewage Systems" and standard engineering design practices for sanitary sewage collection systems based on occupancy and anticipated personnel staffing. 
How the system meets the requirement: The tank specifications are given in the Construction Specification for the Cold Vacuum Drying Facility, W-441-C1, which specifies a 5000 gallon tank.

\subsubsection{Electrical Power}

This section does not apply to this SDD.

\subsubsection{Instrumentation and Control}

1. Requirement: High level and high-high level instrumentation should be provided in the holding tank.

Basis: WAC 246-272-12501, "Holding Tank Sewage Systems" and standard engineering design practices for sanitary sewage collection systems.

How the system meets the requirements: High level and high-high level instrumentation is provided in the holding tank. Instrumentation is connected to the MCS. See SDD SNF-3090, Cold Vacuum Drying Facility Monitoring and Control System Design Description, for details.

\subsubsection{Computer Hardware and Software}

This section does not apply to this SDD.

\subsubsection{Fire Protection}

This section does not apply to this SDD.

\subsection{Testing And Maintenance Requirements}

\subsubsection{Testability}

No special testing beyond that required by the national codes is required.

\subsubsection{Technical Safety Requirements (TSR) Required Surveillances}

This section does not apply to this SDD.

\subsubsection{Non-TSR Inspections and Testing}

This section does not apply to this SDD. 


\subsubsection{Maintenance}

There are no unique sanitary sewage collection system maintenance requirements during the three-year operating life of the CVD Facility other than regular pumping of the waste from the holding tank.

\subsection{Other Requirements}

\subsubsection{Security and SNM Protection}

This section does not apply to this SDD.

\subsubsection{Special Installation Requirements}

Installation requirements shall be described in the specifications.

\subsubsection{Reliability, Availability, and Preferred Failure Modes}

This section does not apply to this SDD.

\subsubsection{Quality Assurance}

The SANS system fabrication quality assurance/quality control program is based on the safety designation of the systems, structures and components as detailed in SNF-4148, Cold Vacuum Drying Facility Master Equipment List and the application of a graded approach as described in HNF-MP-599, Project Hanford Quality Assurance Program Description. 


\subsection{SYSTEM DESCRIPTION}

\subsection{Configuration}

\subsubsection{Description of System, Subsystems, and Major Components}

The system consists of a main 4-inch line designated SANS-001-ABS-4" running through the center of the administrative lavatory area with 2- and 4-inch ABS feeder lines connected to the main line to service the janitors sink and floor drain in Room 110; the sinks in Room 105; the sinks, water closets and floor drains in Rooms 111 and 112; and the showers and floor drains in Rooms 113 and 114. All the pipes are embedded in the concrete floor of the administration area.

A 2-inch ABS line designated SANS-002-ABS-2" is connected to the main line SANS-001ABS-4" in the floor slab of Room 115 and proceeds northerly to a "Y" connection near Room 118. The line then runs in a northeasterly direction approximately 10 feet to another "Y" connection and then north to and up the wall of Room 120 to the ceiling area of Room 120. A 2inch line runs from the second "Y" connection to a floor drain in Room 120. There is also a vent through the roof (11/2-inch VTR) of the process support area in Room 120.

The line is designated SANS-003-ABS-2" from the second "Y" connection and runs north to an elbow in the ceiling of Room 126 where it turns to the west and connects to the floor drain coming from Room 207. There is a 1/2-inch VTR connected to the line as it enters Room 126. The VTR is routed over and up the east wall of Room 126 and through the roof of the process support building. The Room 207-floor drain trap receives water from the non-potable water system to maintain the trap seal.

From the point of its junction with line SANS-002-ABS-2" in Room 115, line SANS-001-ABS4" runs west to the edge of the administration building where it connects with a 4-inch PVC pipe with the same line number designation and on to the buried 5,000 gallon holding tank located approximately 20 feet from the building. The 5,000 gallon holding tank is approximately 8 feet in diameter and 16 feet long and is covered with approximately 2'-0" of soil. The tank is equipped with two level measuring devices that monitor the liquid levels and report high and high-high liquid levels to the MCS in the administration building. The tank also has a normally sealed manway and a 4-inch diameter pump-out pipe and a 3-inch tank vent. The tank vent is connected to line SANS-004-GCS-3" and runs northeasterly to the administration building where it is routed up the wall to a point above the roof.

A 4-ft. by 4-ft., 4-inch thick, reinforced concrete pad covers the area around the pump out connection. The concrete pad is sloped on all sides to the pump connection to allow spills to run back into the tank through small weep holes provided in the pump out pipe. Four corner bollards protect the area over the tank with yellow chains connecting the bollards. 


\subsubsection{Boundaries and Interfaces}

The boundaries and interfaces of the system are the plumbing fixtures and the floor drains and vents through the roof to atmosphere in Rooms $110,111,112,113$, and 114 of the administration area; Rooms 120 and 207 of the process support area; and the holding tank. The floor drain trap in Room 207 interfaces with the non-potable water system trap primer line. The floor drains in Rooms 120 and 207 also interface with drains from reduced pressure back flow preventers in the potable and the non-potable water lines. The holding tank interfaces with the MCS through level indicators/alarms (described in SDD SNF-3090, Cold Vacuum Drying Facility Monitoring and Control System design Description) and the site sanitary waste collection truck which is used to periodically remove the contents of the tank.

\subsubsection{Physical Location and Layout}

The system is located in the administration and process support areas. The layout is shown on Figure 3-1.

\subsubsection{Principles of Operation}

Sewage and effluent from the sinks, lavatories, showers, and floor drains in the administration building and floor drains in the process support area are transported by gravity to the holding tank. The holding tank is periodically pumped and the sewage waste transported to another facility for treatment.

\subsubsection{System Reliability}

This section does not apply to this SDD.

\subsubsection{System Control Features}

There are no specific system control features. Periodic pumping controls the holding tank liquid level.

\subsection{Operations}

\subsubsection{Initial Configurations (Pre-startup)}

This section does not apply to this SDD.

\subsubsection{System Startup}

Start up testing will be specified in the CVD Facility test specification. 


\subsubsection{Normal Operations}

Normal operation of this system is described in Section 4.1.4.

Operational procedures providing detailed information on operating modes and activities (including alarm response, shutdown, etc.) will be developed.

\subsubsection{Off-Normal Operations}

There are no off-normal operations identified for this system.

\subsubsection{System Shutdown}

There is no specific way to shut the system down other than to stop using the facility.

\subsubsection{Safety Management Programs and Administrative Controls}

This section does not apply to this SDD.

\subsection{Testing And Maintenance}

\subsubsection{Temporary Configurations}

This section does not apply to this SDD.

\subsubsection{TSR-Required Surveillances}

This section does not apply to this SDD.

\subsubsection{Non-TSR Inspections, and Testing}

This section does not apply to this SDD.

\subsubsection{Maintenance}

Maintenance procedures will be developed. 
SNF-3080 Rev 0

Appendix A

Source Documents

A-1 
W-441-C1, Construction Specification for the, Cold Vacuum Drying Facility, Richland, Washington, Sections 02700, Underground Utilities, 15400 Plumbing Piping, 15450 Plumbing Fixtures and Trim, and 15455 Underground Storage Tank,

HNF-SD-SNF-DRD-002, 1999 Cold Vacuum Drying Facility Design Requirements Document, Rev. 4, Fluor Daniel Hanford, Incorporated, Richland, Washington.

HNF-3553, Spent Nuclear Fuel Project Final Safety Analysis Report, Annex B, Cold Vacuum Drying Facility Final Safety Analysis Report, DRAFT, DE\&S Hanford, Incorporated, Richland, Washington.

HNF-MP-599, Project Hanford Quality Assurance Program Description, Fluor Daniel Hanford, Incorporated, Richland, Washington.

SNF-2356, 1999, Spent Nuclear Fuel Project Cold Vacuum Drying Facility Operations Manual, Rev. 1, Numatec Hanford Corporation, Richland, Washington.

SNF-4148, 1999, Cold Vacuum Drying Facility Master Equipment List, Rev. 0A, Numatec Hanford Corporation, Richland, Washington. 
SNF-3080 Rev 0

Appendix B

System Drawings

B-1 
SNF-3080 Rev 0

H-1-82092, Sheet 1 Of 1, Cold Vacuum Drying Facility Civil Site Plan, Legend

H-1-82124, Sheet 2 of 2, Cold Vacuum Drying Facility Structural Foundations Sections and Details

H-1-82222, Sheet 1 of 2, Cold Vacuum Drying Facility Mechanical Utilities WTR \& Compressed Gases $P \& I D$

H-1-82225, Sheet 1 of 1, Cold Vacuum Drying Facility Mechanical Utilities $1^{\text {st }}$ Floor Drainage Systems

H-1-82229, Sheet 1 of 2, Cold Vacuum Drying Facility Mechanical Utilities Sections and Details 
SNF-3080 Rev 0

Appendix C

System Procedures

C-1 
SNF-3080 Rev 0

Systems procedures have not been developed at this time. 


\section{DISTRIBUTION SHEET}

\begin{tabular}{|c|c|c|c|c|c|}
\hline \multirow{2}{*}{$\begin{array}{l}\text { To } \\
\text { Distribution }\end{array}$} & \multirow{2}{*}{\multicolumn{3}{|c|}{$\begin{array}{l}\text { From } \\
\text { Technical Integration }\end{array}$}} & \multicolumn{2}{|l|}{ Page 1 of 1} \\
\hline & & & & \multicolumn{2}{|c|}{ Date June 14, 1999} \\
\hline \multirow{2}{*}{\multicolumn{4}{|c|}{$\begin{array}{l}\text { Project Title/Work Order } \\
\text { SNF-3061, SNF-3066, SNF-3067, SNF-3072, SNF-3073, SNF=3074, } \\
\text { SNF-3077, SNF-3078, SNF-3079, SNF-3080, SNF-3081. }\end{array}$}} & \multirow{2}{*}{\multicolumn{2}{|c|}{$\begin{array}{l}\text { EDT No. } 626308,62631 \\
\text { ECN No. NA }\end{array}$}} \\
\hline & & & & & \\
\hline Name & MSIN & $\begin{array}{l}\text { Text } \\
\text { With All } \\
\text { Attach. }\end{array}$ & Text Only & $\begin{array}{l}\text { Attach./ } \\
\text { Appendix } \\
\text { Only }\end{array}$ & $\begin{array}{l}\text { EDT/ECN } \\
\text { Only }\end{array}$ \\
\hline W. C. Alaconis & $\mathrm{R} 3-86$ & $\mathrm{X}$ & & & \\
\hline L. L. Blehm & $X 3-86$ & $X$ & & & \\
\hline K. A. Boes & $\mathrm{R} 3-86$ & $X$ & & & \\
\hline J. R. Brehm & R3-86 & $\mathrm{X}$ & & & \\
\hline C. S. Haller & R3-11 & $X$ & & & \\
\hline L. C. McKenzie & S2-45 & $\mathrm{X}$ & & & \\
\hline S. L. Mischke & R3-86 & $X$ & & & \\
\hline C. C. Pitkoff & $\mathrm{R} 3-86$ & $\mathrm{X}$ & & & \\
\hline CVD Project File & R3-86 & $\mathrm{X}$ & & & \\
\hline SNF Project File & R3-11 & $X$ & & & \\
\hline
\end{tabular}

